\title{
THE FTC'S ANNUAL LINE-OF-BUSINESS REPORTING PROGRAM
}

The Federal Trade Commission (FTC) has recently implemented a Line-of-Business (LB) reporting program $^{1}$ in an effort to provide more meaningful financial information on industry in the United States. Under the program, large conglomerate corporations engaged in several lines of business are being required to provide the FTC with detailed financial information on their activities according to particular product lines. After obtaining the data, the FTC plans to publish statistical reports on aggregate profits, costs, and other financial data for each specific line of business. As might be expected, the program lias been the subject of nuch recent debate over the need for the inforination ${ }^{2}$ as balanced against the burdens imposed on private industry by the reporting requireinents. ${ }^{3}$

As a preliminary matter, this Note will outline the present status of the LB program, its background, and the need for such a prograin. The legality of the prograin will then be assessed through an examination of the scope of the Coinmission's authority to conduct general economic and financial investigations. This analysis will be focused upon two broad and independent inquiries: (1) whether the FTC has the authority to compel corporations to respond to LB reports and, if so, what the limitations are on the exercise of that authority, and (2) whether the FTC should be restrained froin

THE FOLLOWING CITATIONS WILL BE USED IN THIS NOTE:

Bureau of Economics Staff Report, Federal Trade Commission Lime of Business Reporting Program [heremafter cited as Bureau Staff Report];

Report to the Comptroller General of the United States on the Evaluation of the Federal Trade Commission's Proposed Annual Line of Busmess Report (Form LB) [hereinafter cited as Report to the Comptroller General].

Copies of all sources cited in this Note are on file at the offices of Duke Law Journal, Durham, North Carolina.

1. The LB reporting forms for the first year of the program were mailed in August, 1974 , and they request information for fiscal years ending between July 1, 1973, and June 30, 1974. FTC Line of Business Program Questions and Answers, No. LB-2.

2. Proponents argue that the program is needed to provide the product-line data that is rapidly becoming unavailable due to the growth of multiproduct corporations in American industry. See, e.g., Letter from Representative Peter Rodino and Senator Philip Hart to Senator John McClellan and Representative George Mahon, May 9, 1974, reprinted in 663 BNA ANTITRUST \& TRADE REG. REP. H-1 (May 14, 1974).

3. See, e.g., Letter from Richard D. Godown, General Counsel of the National Association of Manufacturers, to Phillip S. Hughes, Assistant Comptroller General, April 15,1974 , at $1-2$. 
publishing the aggregate LB reports as currently planned because of a possibility of disclosure of confidential individual company statistics.

\section{Outline of the Line-Of-Business Program}

Under the current version of the LB program, ${ }^{4}$ many of the largest United States corporations ${ }^{5}$ are being required annually to provide the FTC witl financial information on their activities in over two hundred industrial categories, or lines of busmess. ${ }^{6}$ The information to be provided mcludes statistics on sales, expenses (including costs for advertising and researcli and development), and values of assets (including plant, property, and equipment) used in each product line. ${ }^{7}$ These particular statistics are, in the Commission's view, important indicators of the competitive performance of American industry. ${ }^{8}$ After acquisition of this imformation, the FTC staff will aggrcgate the data from all reporting corporations and publish statistics for eacli imdustrial category. ${ }^{\circ}$ The FTC plans to keep the data for individual compamies confidential, ${ }^{10}$ and the information for any par-

4. The present version represents the third revision of the program since August, 1973. It has been revised in response to numerous comments and criticisms from interested parties including business firms, consumer groups, and congressmen. Report to the Comptroller General 2. An earlier LB proposal was submitted to the Office of Management and Budget for approval in the fall of 1970 but was rejected. 119 CoNG. REc. S 13,442 (daily ed. July 14, 1973) (remarks of Senator Hart).

5. A total of 345 corporations are currently participating in the program. 667 BNA ANTtTrust \& Trade REg. Rep. A-3 (June 11, 1974).

6. There are a total of 228 line-of-business categories, 219 of which are in manufacturing. Bureau Staff Report 15. Unless a company keeps its own records according to lines of business, it will be allowed to report the information by plant or other economic unit. FTC Form LB, Annual Line of Business Report, item D, at 7. This means that the statistics for each plant or other econounic unit will be reported according to its primary line-of-business category, regardless of the fact that some operations in the establishment may be in other lines of business. Id. Any line of business which has less than ten million dollars in sales will be reported in a iniscellaneous category. Questions and Answers, supra note 1, No. LB-4.

7. See FTC Form LB, supra note 6, item E, at 10-14.

8. See Bureau of Econounics Staff, Federal Trade Commission, FTC Form LB Supporting Statement, at 1.

9. The published report for each line-of-business category will resemble a fairly complete income statement and an abbreviated balance sheet. Bureau Staff Report 22. Other components of the report will include tables showing rates of return on assets and profit margins on sales, and an analysis published in the form of a matrix showing the extent of secondary product contamination in the statistics. Id. at 24. Secondary product contamination occurs when financial data are reported in a line of business different from their proper category. This can happen, for example, when some operations in an establishment are in a category other than the primary classification of the establishment. See note 6 supra.

10. FTC Resolution Requiring Annual Line of Business Reports from Corporations, 
ticular reporting cell will not be published unless data from at least four firms has been submitted and aggregated for that particular cell. ${ }^{11}$

The current LB questionnaire, revised in response to suggestions arising out of administrative hearings, ${ }^{12}$ was submitted to the General Accounting Office for review and clearance pursuant to the recently amended Federal Reports Act. ${ }^{13}$ The FTC had to defer gathering information $^{14}$ until the Comptroller General specifically found that the method proposed to collect the inforination would impose the minimum burden on businesses and that the data was not presently available from another source within the government. ${ }^{15}$ The Acting Comptroller General approved the questionnaire, but limited his approval to the first year, with future approval conditioned upon the FTC's increasing the rehability of the information collected and published. ${ }^{16}$

August 2, 1974, 39 Fed. Reg. 30,377 (1974); Rules and Procedures for the Use of Confidential Individual Company Data Collected Under the FTC's Line of Business Report Program, 39 Fed. Reg. 30,970 (1974).

11. See Letter from Charles Tobin, Secretary of the FTC, to Ira M. Millstein and Mark A. Jacoby, Weil, Gotshal \& Manges, Sept. 24, 1974, at 5 (FTC respouse to motion to quash).

12. Report to the Comptroller General 2.

13. 44 U.S.C.A. $\$ 3512$ (Supp. 1974), amending 44 U.S.C. $\$ 3506$ (1970). At the time the LB program was initially proposed, the Federal Reports Act required the Office of Management and Budget (OMB) to review all federal ageucy information-collection programs to determiue whether or not the program was necessary for the proper functioning of the agency. 44 U.S.C. $\$ 3506$ (1970), as amended, 44 U.S.C.A. $\$ 3512$ (Supp. 1974). During the pendency of the OMB review of the proposal, the Act was amended to substitute the General Accounting Office (GAO) as the reviewing agency. The principal reason for the amendment was appareutly that the OMB, as part of the executive branch, should not have a veto power over the programs of independent regulatory agencies. 119 CoNG. REc. S13,442 (daily ed. July 14, 1973) (remarks of Senator Hart). But a very significant congressional motive was to allow the FTC to implement the LB program without interference from the OMB, which had blocked an earlier LB proposal in 1971. See id.

14. However, "the independent regulatory agency shall make the final determination as to the necessity of the information in carrying out its statutory responsibilities and whether to collect snch information." 44 U.S.C.A. \$ 3512(d) (Supp. 1974).

15. Id. $\$ 3512(\mathrm{a})$.

16. Letter from R.F. Keller, Acting Coinptroller General, to Lewis Engman, Chairman of the FTC, May 13, 1974.

The program was found consistent with the Federal Reports Act, subject to three provisos. First, approval was "limited to the initial round of reports," with approval of future rounds "subject to significant reductions in or elimination of the problems which make the initial data unreliable . ..."Id. Second, the FTC was directed to condnct "intensive discussions with business representatives" aimed at mcreasing accuracy and reducing the compliance burden. Id. Third, the FTC was to explore "with other federal agencies . . . the possibility of coordinating or consolidating its LB data needs with data collected by those agencies." Id. The GAO apparently took the position that reliability of resuits was a factor in the determination of minimum burden. See Report to 
Following the initial mailing of the LB questionnaires, the business community immediately registered its opposition to the program by filing nuinerous motions with the FTC to quash the Commission's order to file the LB reports. ${ }^{17}$ The Commission overruled these motions but granted additional time to file new motions limited to the issues of maintaining the confidentiality of individual company data and the burden of compliance, directing that the claims be factually substantiated. ${ }^{18}$ Several companies did file second motions ${ }^{19}$ which challenged the LB orders on the grounds of unreasonable burden, ${ }^{20}$ but more importantly they introduced evidence that sophisticated mathematical pattern-recognition techniques could be used to disaggregate the published LB report so that confidential individual company statistics could be discovered. ${ }^{21}$ In spite of those claims, the Commission agam overruled the motion. ${ }^{22}$ Althougl the first LB reports were due from participating corporations during January, $1975,{ }^{23}$

the Comptroller General 13.

The FTC responded to this limited approval by denying that the Federal Reports Act gave the Comptroller General the authority to condition continuation of the program. See Letter from Lewis Engman, Chairman of the FTC, to Senator Philip Hart, May 15, 1974, at 2. In the Commission's view, "GAO comments under the statute should be restricted to questions of duplication and burden and should not be addressed to other issues such as reliability of data." Id. Since the Commission had determined that the program would generate information "sufficiently reliable to warrant its collection," it considered the matter closed. Letter from Charles Tobin, supra note 11, at 1. Mr. Tobin wrote: "Comments of the Comptroller General concerning the unreliability of information to be collected are not binding on the Commission, because the decision as to the necessity and usefulness of such data is committed by law to the Commission ....."Id.

17. At least 193 motions to quash were filed. 696 BNA ANTIrrust \& Trade Reg. REp. A-13 (Jan. 14, 1975). The grounds for these motions to quash included claims that the Commission had exceeded its statutory authority in implementing the LB program because the data collected would be unreliable and the order to file LB reports was excessively burdensoine, and that the order to file LB reports was unlawful because it failed to protect against the disclosure of individual company data. See Motion to Quash Order to File Special Report and to Grant Ancillary Relief, In re Aluminum Co. of America (F.T.C., filed Aug. 20, 1974).

18. Letter from Charics Tobin, supra note 11, at 1,5 .

19. See Motion to Quash Order to File Special Report as Modified and to Grant Ancillary Relief at 3, In re Aluminum Co. of America (F.T.C., filed Oct. 4, 1974).

20. Id. at 10-11.

21. See generally Memorandum on Disaggregation of line-of-Business Data from R. Christensen \& T. Reichert to Weil, Gotshal \& Manges, Oct. 26, 1974.

22. 696 BNA ANtitrust \& Trade Reg. Rep. A-13 (Jan. 14, 1975). The Commission found that the disaggregation hypotheticals put forward by the moving parties were improbable, and in any case, the program had been structured to minimize the dangers of disclosure of individual data. As for the issue of the burden of preparation, the Com: mission maintained the position that the data could be gathered inexpensively by complying corporations, and hence the order was not unduly burdensome. Id.

23. Id. 
many reports were not submitted because actions had been brought in two federal courts to enjoin enforcement of the LB orders, and it now appears that final implementation of the program may be delayed considerably. ${ }^{24}$

According to the FTC, the LB program is necessary because current reporting programs and other currently available sources of financial information on American industry have proven inadequate ${ }^{25}$ to enable the FTC to fulfill its statutory responsibilities of investigating the extent of competition in the United States economy and reporting these results to the government and the public. ${ }^{26}$ In the Commission's view, this kind of systenratic, comprehensive reporting on the financial status of narrowly defined imdustrial categories will generally improve economic performance in American industry by disclosing the performance of individual industries. ${ }^{27}$ The FTC suggests that the LB information will help to improve the functioning of capital markets by exposing the rate of return on capital in particular industries. ${ }^{28}$ It will also aid the federal government in its development of an overall national economic policy. ${ }^{29}$ Further-

24. Actions were brought by companies challenging the program in federal district courts in Delaware and New York. In the New York suit, the court has recently denied a petition for preliminary injunctive relief on the ground that there had been no showing of irreparable injury or hardship to warrant such rehief. Aluminum Co. of America v. FTC, 700 BNA Antitrust \& Trade Reg. Rep. A-6 (S.D.N.Y., Feb. 5, 1975). In the Delaware suit, however, the court granted preliminary injunctive relief to seven companies on the ground that the progran violates rulemaking provisions of the Administrative Procedure Act (APA), 5 U.S.C. $\$ 553$ (1970). A.O. Snith Corp. v. FTC, 702 BNA Antitrust \& Trade Reg. Rep. A-1 (D. Del., Feb. 19, 1975). Meanwhile, the FTC has petitioned for enforcement of its orders against thirty-four companies under section nine of the FTCA, 15 U.S.C. \$ 49 (1970). FTC v. American Standard, Inc., 702 BNA ANTitrust \& Trade Reg. ReP. A-1 (S.D.N.Y., Feb. 20, 1975). As of February 25, 1975, 197 of the 345 participating conipanies had filed LB reports with the Commission. Id.

25. Such programs as the FTC's long-standing Quarterly Financial Report Series (QFR) and the Securities \& Exchange Commission's $10-\mathrm{K}$ reports have been found inadequate by the FTC. See Bureau of Economics Staff, supra note 8, at 6; Address by Calvin Collier, General Counsel of the FTC, before the Association of General Counsel, May 10, 1974, at 2. Similarly, individual conpany annual shareholder reports are not adequate sources of LB data, althougl the New York Stock Exchange has adopted a recommendation of the Financial Executives Institute that product line reporting be included in annual financial reports. See Report to the Comptroller General 4-5.

26. Bureau of Economics Staff, supra note 8, at 1.

27. Bureau Staff Report 7.

28. Statement of Frederic Schierer, staff member of the FTC, before the Fifth Annual National Conference of the National Investor Relations Institute, Oct. 21, 1974; see Bureau Staff Report 7.

29. See Letter from Representative Peter Rodino and Senator Philip Hart, supra note 2. Congress and the President will obviously be much better equipped to deal with the nation's economic problems if this sort of detailed information on American industry 
more, although no individual company's data will be disclosed to the FTC enforcement staff, ${ }^{30}$ the aggregate reports will aid the FTC in its antitrust enforcement policy planning by pimpointing areas of possible anticompetitive activity. ${ }^{31}$

\section{Legality of the FTC's Line-of-Business Program}

\section{Authority to Require LB Reports from Corporations}

The FTC's power to compel corporations to file reports containing line-of-business data is based upon the broad investigatory authority granted in the Federal Trade Commission Act (FTCA), ${ }^{32}$ which authorizes the Commission to conduct investigations concerning the "organization, business, conduct, practices and management of any corporation engaged in commerce," 33 and in particular, "to require, by general or special orders, corporations engaged in commerce . . . to file with the Commission in such form as the Commission may prescribe annual or special . . . reports or answers in writing to specific questions . . ..."34

Since its inception the FTC has successfully impleinented many economic and financial reporting schemes. ${ }^{35}$ While previous FTC attempts to implement a comparative reporting program for large conglomerate corporations have been blocked, ${ }^{36}$ including an earlier

is available. Congress' recent experience in trying to obtain meaningful data on the petroleum industry in connection with its development of energy policy provides an illustration of this point. Id.

30. See Rules and Procedures for the Use of Confidential Individual Company Data, supra note 10.

31. Bureau of Economics Staff, supra note 8, at 2. Because of the Commission's limited resources, the problem of enforcement priorities has for many years been an extremely troublesome issue. MacIntyre \& Volhard, The Federal Trade Commission, 11 B.C. IND. \& CoM. L. Rev. 723, 733 (1970).

32. Pub. L. No. 93-637, §§ 201(b), 203(a)(1)-(2) (Jan. 4, 1975), amending 15 U.S.C. $\$ \S 46(a)$-(b) (1970), reprinted in 4 TRADE REG. REP. \ $25,257$.

33. Pub. L. No. 93-637, $\S \$ 201$ (b), 203 (a) (1) (Jan. 4, 1975), amending 15 U.S.C. \& 46(a) (1970), reprinted in 4 TRADE REG. REP. TI 25,257.

34. Pub. L. No. 93-637, $\S \S 201$ (b), 203 (a) (2) (Jan. 4, 1975), amending 15 U.S.C. \& 46(b) (1970), reprinted in 4 TRADE REG. REP. II 25,257. The APA forbids agencies from requiring reports and demanding information "except as authorized by law." 5 U.S.C. $\$ 555$ (c) (1970). Jf the FTC has the authority to require reports under section 6(b) of the FTCA, then the APA provision is satisfied. See United States v. Morton Salt Co., 338 U.S. 632, 644-47 (1950). Refusal to respond to an FTC order to file a report subjects the corporation to a $\$ 100$ per day penalty for every day of delinquency. Pub. L. No. 93-637, $\$ 203($ c)(1), (2) (Jan. 4, 1975), amending 15 U.S.C. $\$ 50$ (1970), reprinted in 4 TRADE REG. REP. 17 25,257.

35. See generally Boyle, Economic Reports and the Federal Trade Commission: 50 Years' Experience, 24 FED. BAR J. 489, 496-502 (1964).

36. In 1962, the Commission decided to undertake an investigation of some of the 
version of the LB program, ${ }^{37}$ the recent attempts to implement the current LB program have been more successful, in part because of the recent change in the Federal Reports Act. ${ }^{38}$

Despite the extensive history of comprehensive economic and financial reporting programs, the Commission's use of the reports authority in this area has seldom been challenged in the courts. ${ }^{30}$ As a consequence, the judicial guidelines on the exercise of the reports authority have generally arisen from cases concerned with more specific reports ordered by the FTC in its enforcement activities. Consistent with the apparent congressional imtent to give the FTC broad reports authority, ${ }^{40}$ the courts have interpreted that power expan-

largest United States manufacturing corporations, seeking infornation on company products, merger aetivity, and relationships to other corporations. This program generated substantial controversy, and in the FTC's 1964 appropriation bill, Congress imcluded a provision that no funds were to be used for an economic questionnaire or financial study of intercorporate relations. Pub. L. No. 88-507, 78 Stat. 640 (Aug. 30, 1964); see Boyle, supra note 35 , at 501 .

37. In 1971, an earlier LB proposal was rejected by the OMB which at that time was authorized by the Federal Reports Act, 44 U.S.C. $\$ 3506$ (1970), as amended, 44 U.S.C.A. $\$ 3512$ (Supp. 1974), to review FTC information-collection programs. 119 CoNG. REC. S13,442 (daily ed. July 14, 1973) (remarks of Senator Hart).

38. See 44 U.S.C.A. $\$ 3512$ (Supp. 1974), amending 44 U.S.C. $\$ 3506$ (1970). See note 13 supra. A current but unenacted appropriations bill for the FTC would finance the FTC's LB costs for gathering information from 500 corporations. See 120 CoNG. REc. H10,223 (daily ed. Oct. 9, 1974); id. at S20,053 (daily ed. Nov. 25, 1974).

39. The cases in which the use of the reports authority has been challenged in general economic and financial investigations are dated and not very useful. See, e.g., FTC v. Millers' National Fed'n, 47 F.2d 428 (D.C. Cir. 1931) (an investigation of costs, prices, and profits in the flour and bread industry; the court holding that the Commission's authority to order production of the information could not be determined in a suit brought to enjoin the FTC order); FTC v. Maynard Coal Co., 22 F.2d 873 (D.C. Cir. 1927) (investigation of coal and steel industries to acquire financial information; the court holding that an action to enjoin FTC enforcement of the order did not he because of an adequate remedy at law); FTC v. Claire Furnace Co., 285 F. 936 (D.C. Cir. 1923), rev'd on other grounds, 274 U.S. 160 (1927) (investigation to acquire information on coke and coal imdustries; the lower court enjoining the FTC orders on the ground that the FTC lacked the authority to seek information on intrastate counmerce; the Supreme Court reversing on procedural grounds).

40. The powers granted by 15 U.S.C. $\$ \$ 46(\mathrm{a})-(\mathrm{b})$ (1970), as amended, Pub. L. No. 93-637, $\$$ 201(b), 203(a) (1)-(2) (Jan. 4, 1975), reprinted in 4 TRADE REg. REP. II 25,257 , see notes 32-34 supra and accompanying text, were founded upon the investigative and publicity powers of the FTC's predecessor, the Bureau of Corporations. The Bureau of Corporations was part of the executive branch and engaged almost exclusively m economic investigations and reports. MacIntyre \& Volhard, supra note 31 , at 725 . Congress considered these investigative and publicity powers of primary importance in promoting "an elevated business standard and a better business stability," and in providing a check on "the growth of monopoly." H.R. REP. No. 533, 63d Cong., $2 \mathrm{~d}$ Sess. 3, 4 (1914). As one commentator has concluded:

[T]here seems to have been little doubt of what the reporting powers given 
sively, with minimal limitations. Thus, in the leading case of United States v. Morton Salt Co., ${ }^{41}$ where the FTC ordered the corporation to file special reports to monitor coinpliance with the agency's cease and desist order, the Supreme Court sustained the report requireinent, indicating that the reports provision could be used in the furtherance of any FTC statutory duty. ${ }^{42}$ Furthermore, the court recognized that a reasonable demand for reports ${ }^{43}-$ one within the authority of the agency, seeking relevant information, and not too broad or unreasonably burdensome ${ }^{44}$ - even if initiated to satisfy "nothing inore than agency curiosity," 45 would not violate the fourth amendment proscriptions against unreasonable searches and seizures or the fifth amendment due process clause.

Cases subsequent to Morton Salt have likewise interpreted the FTC reports authority broadly, ${ }^{46}$ and the prevalent judicial attitude toward administrative demands for information has been one of deference to the agency. Once the court is satisfied that the agency has the authority to demand the information, the criteria of relevancy and lack of unreasonable burden are easily net. Typically, agency orders have been considered presumptively relevant-no affirmative denonstration of relevance by the agency is required. ${ }^{47}$ Similarly, courts

to the Commission were supposed to accomplish. The Commission was to have all necessary powers to enable it to determine the facts with respect to certain industries and practices, and, having ascertained the facts, to make them known to Congress and the general public ... B Boyle, supra note 35 , at 491.

41. 338 U.S. 632 (1950).

42. Id. at 649. "[I]t would appear to grant ample power to order the reports here in question. Respondents are in the class subject to inquiry . . . and the matter to be reported would seem to be as to business conduct and practices about which the Commission is authorized to imquire." Id.

43. In Morton Salt, the Court emphasized and redefined the test it had earlier established in Oklahoma Press Publishing Co. v. Walling, 327 U.S. 186 (1946), where the Court had stated: "The gist of the protection is in the requirement, expressed in terms, that the disclosure sought shall not be unreasonable." Id. at 208.

44. 338 U.S. at 652 .

45. Id.

46. In the leading case of St. Regis Paper Co. v. United States, 368 U.S. 208 (1961), the Court sustained a Commission order requiring the corporation to file special reports for the purpose of uncovering possible antitrust violations prior to the issuance of a complaint. In United States v. Litton Indus., Inc., 462 F.2d 14 (9th Cir. 1972), the Ninth Circuit held that the FTC could require a corporation to file a report relating to a general investigation of conglomerate corporation inergers and at the same time maintain a separate divestiture action against the same corporation under the antitrust laws. See also Genuine Parts Co. v. FTC, 445 F.2d 1382 (5th Cir. 1971) (discussed in note 48 infra).

47. See CAB v. Hermann, 353 U.S. 322 (1957), where the Supreme Court reversed per curiam a lower court holding that the relevance of each item sought by the Civil 
have been reluctant to quash administrative demands for information on the ground that they are too burdensome, particularly if the information sought is relevant to the inquiry. ${ }^{48}$ However, one court has stated that "it inust . . . appear that there is some reasonable proportion between the public value of the information likely to be obtained and the private annoyance and irritation it will occasion." 49

The LB program as presently constituted arguably satisfies each of the judicially imposed requirements of authority, relevancy, and lack of unreasonable burden. First, such a prograin seems to be expressly authorized by the FTCA, which einpowers the FTC to conduct general investigations imto busimess structure, conduct, and management, as well as to require corporations to respond to Commission inquiries with periodic reports or answers. ${ }^{50}$ Further, since the purpose of the LB program is to provide the government with particularized statistics on prescribed lines of business, the FTC request for information is by definition relevant. ${ }^{51}$ The prohibition of unreasonable

Aeronautics Board in its investigation must be established before the order would be enforced.

48. See Withrow, Investigatory Powers of the Federal Trade Commission-Constitutional and Statutory Limitations, 24 FED. B.J. 456, 481 (1964). The question of unreasonably burdensome compliance is almost invariably tied to the question of relevancy, and the mere fact that an order is extremely broad or burdensome is not very persuasive if all the information sought is in fact relevant to the inquiry. Id. In Genuine Parts Co. v. FTC, 445 F.2d 1382 (5th Cir. 1971), the FTC had ordered the corporation to file a special report to determine if the corporation had violated the antitrust laws in making certain corporate acquisitions. The court responded to the corporation's contentions that the FTC order was too broad and compliance would be unreasonably burdensome by noting first that the information sought went "to the very heart of the inquiry," id. at 1391, and then concluding that the order was not burdensome when "considered in light of the pertinent responses" it would produce, $i d$.

49. FTC v. Baltimore Grain Co., 284 F. 886, 889-90 (D. Md. 1922), aff'd, 267 U.S. 586 (1925); cf. FCC v. Colm, 154 F. Supp. 899 (S.D.N.Y. 1957). In Cohn, the court stated: "There is a delicate balance between the necessity of obtaining information required in the public interest in furtherance of a lawful inquiry, and the onerous burdens which the furnishing of this information may place on these respondents." Id. at 908 .

50. Pub. L. No. 93-637, §§ 201(b), 203(a)(1)-(2) (Jan. 4, 1975), amending 15 U.S.C. \$\$ 46(a)-(b) (1970), reprinted in 4 TRADE REG. REP. II 25,257. See notes 32-34 supra and accompanying text. The program is but another in a long line of FTC general and economic reporting programs that have been implemented through the use of the reports authority. See generally Boyle, supra note 35, at 496-502. The legislative history of the reports provision clearly indicates that this was the type of program that Congress had in mind when it gave the Commission this authority, see note 40 supra; in any case, the courts have construed the provision broadly, even beyond the confines of general economic and financial reporting programs. See, e.g., St. Regis Paper Co. v. United States, 368 U.S. 208 (1961); United States v. Morton Salt Co., 338 U.S.' 632 (1950). See notes $41-49$ supra and accompanying text.

51. As was noted earlier, the mere FTC request for the information will create a presumption of relevancy. See note 47 supra and accompanying text. 
burden, however, is not so easily resolved. It has been suggested that an agency's demand for information is unreasonably burdensome when the private cost of generating that information outweighs the public benefit of obtaining it. ${ }^{22}$ While it is difficult to neasure these quantities precisely, at least a gross approximation must be made if reasonableness is to be determined. If the information gathered in the LB program is to be usefully compared and aggregated by the public and the government, it must be reported according to uniforin classifications. As currently constructed, however, the information to be produced will suffer from nonuniformities and distortions. ${ }^{53}$ Essentially, the problem is one of applying uniform accounting standards to the data. Subjective classifications of the common costs of producing items which fall within more than one LB category, ${ }^{54}$ nonuniform allocation of intra-company transfer expenses, ${ }^{55}$ and the FTC's adoption of the establishment basis of reporting ${ }^{56}$ all tend to decrease the rehability of the LB information..$^{57}$

Notwithstanding the less than perfect reliability of the aggregate data, the information produced froin the LB program will be a sub-

52. See note 49 supra and accompanying text.

53. The Assistant Comptroller General has found that the data produced under the program will be "unreliable at best, and may be seriously misleading." Report to the Comptroller General 15.

54. The FTC's proposal for dealing with common costs is: (1) it will accept allocations of cominon costs already made by reporting companies and apparently intends to aggregate the resulting data although widely different allocation methods may have been used by different conpanies; and (2) for comnion costs not allocated by the reporting companies, the FTC will apply its own unspecified allocation formulas. Id. at 8.

Hence, the costs included in each LB category will be the result of a unilateral determination by either the reporting companies or the FTC, with consequent sacrifice of accuracy.

55. If a company is vertically integrated so that the output of one segment of its operation within one line-of-business category is forwarded to another segment of its operation in another FTC category for further processing, some arbitrary computations must be performed in order to determine the proper "sales" and "costs" to be reported in each category. Although methods of computing transfer costs vary widely among companies, see id. at 9, the FTC plans to accept the methods used by the companies and to aggregate the resulting figures, see id. Obviously, this process can introduce substantial inaccuracy into the aggregated data.

56. The establishment basis of reporting allows conipanies to report the data for a single plant in the category of the "primary activity" of that plant. See FTC Form LB, supra note 6 , item D, at 7 . As a consequence of the establishment basis, data appropriately reported in other categories is reported in the primary category.

57. As the Assistant Comptroller General has assessed the overall situation, the aggregated profit figure for each FTC category will be the end product of subjective judgment by each company in allocating costs conimon to two or more FTC categories and in coinputing transfer costs, and an arbitrary allocation of all the sales, costs, and profits of a nulticategory establishment to the category to which the primary activity of the establishment is assigned, $\operatorname{Re}-$ port to the Comptroller General 6. 
stantial improvement over any currently available statistics. ${ }^{58}$ Furthermore, the Commission has determined, and its determinations have traditionally been given deference, ${ }^{59}$ that the public value of the information to be obtained does in fact justify the expense of compliance. $^{.0}$ Finally, the inaccuracies of the LB program are attributable in large part to the FTC's efforts to reduce the compliance burden on the reporting entities by accepting some of the accounting imformation in the form it is now being gathered by individual compames rather than requiring thein to keep an additional set of books for purposes of FTC reporting requirements. ${ }^{61}$ Although the estimates of the costs of compliance vary dramatically, ${ }^{62}$ even the highest estimates seen less significant when compared to the profits of the reporting companies, which are among the largest corporations in the United States.

\section{May the FTC Publish the Aggregate LB Reports?}

The FTCA gives the Commission the discretionary authority to publish the information it gathers under its reports authority, except that "trade secrets and names of customers" are specifically excepted from public disclosure. ${ }^{63}$ In addition to the "trade secrets" prohibition, the Commission may be restrained from the publication of other business secrets under the general limitation on the disclosure of confidential information. The propriety of the proposed public disclosure

58. See Letter from Lewis Engman, supra note 16, at 2 . See notes 25-30 supra and accompanying text.

59. See notes $46-49$ supra and accompanying text.

60. The Coinmission rejected the argument that the burden of compliance was unreasonable in denying the companies' motion to quasli the FTC orders to file special reports. See Statement of Federal Trade Commission, Jan. 9, 1975, on Rejection of Renewed Motions to Quash its Line of Business Reporting Program, reprinted in 696 BNA ANTITRUST \& TRADE REG. REP. F-1 et seq. (Jan. 14, 1975). 3.

61. See Bureau Staff Report 20-21; Letter from Lewis Engman, supra note 16, at

62. The FTC currently estimates the costs will be $\$ 10,000$ to $\$ 20,000$ per corporation for the first year, and $\$ 5,000$ to $\$ 10,000$ per year for succeeding years. On the other hand, some coinpanies estimate that it will cost them from $\$ 350,000$ to $\$ 1,800,000$ for the imitial year, and $\$ 95,000$ to $\$ 325,000$ per year for succeeding years. Report to the Comptroller General 10.

63. See 15 U.S.C. $\$ 46(f)$ (1970), which in pertment part provides that the Commission shall have the power "[t]o make public from time to time such . . . information obtained by it hereunder, except trade secrets and names of customers, as it shall deem expedient in the public interest ... ." Section 10 of the FTCA, 15 U.S.C. \& 50 (1970), contains an additional restraint on the public disclosure of confidential information: "Any officer or employee of the Commission who shall make public any information obtained by the Commission without its authority, unless directed by a court, shall be deemed guilty of a misdemeanor ....." 
by the FTC of aggregated LB data must be examined in hight of these two limitations.

Arguably, the trade secrets exception is broad enough to encompass all financial data of competitive significance, ${ }^{64}$ such as that being reported by individual companies in the LB reports. While there is apparently no judicial definition of trade secrets in the context of the reports authority of the FTCA, the term "trade secrets" in other situations has been interpreted to include this kind of otherwise confidential business information. ${ }^{65}$ Furthermore, under substantive trade secret law, nontechnological internal business organization information and information on the methods of operation, such as will be gathered in the LB program, can be characterized as trade secrets. ${ }^{68}$ However, in the context of agency adjudications, the FTC has been imconsistent in its treatment of confidential busimess information. In H. P. Hood \& Sons, Inc., ${ }^{67}$ the FTC established a dicliotomous approach to the protection of confidential information. Business records such as cost and profit data were held to be entitled to a lesser degree of protection than traditional trade secrets sucll as secret formulae and rcsearch processes. Busmess records would be protected from public disclosure only "in exceptional circumstances upon a clear showing that an irreparable injury will result," sumption of the requisite degree of injury would arise when any dis-

64. The legislative history of 15 U.S.C. $\$ 46(f)$ (1970) tends to support this proposition. See 51 CoNg. Rec. 12,744-45 (1914) (remarks of Senator Weeks). Senator Weeks, an opponent of the trade commission bill, expressed concern over the possible public disclosure of "the essential facts connected with the organization, stockholders, financial condition, and general business conduct" of corporations required to disclose this information to the FTC, id. at 12,744, further noting that this kind of information takes "on elements of a trade-mark," id. at 12,745. In response to this sort of criticisin, the provision in the original bill preventing disclosure of "trade processes," see 51 CoNG. REC. 10,377 (1914), was changed to "trade secrets," see 15 U.S.C. $\$ 46(f)$ (1970).

65. In connection with the protection of trade secrets in litigation, Professor Wigmore noted that trade secrets include not only "chemical and physical composition of substances employed, and . . . the mechanical structure of tools and machines, but also ... such other facts of a possibly private nature as the names of customers, the subjects and amounts of expeuse, and the like." $8 \mathrm{~J}$. WIGMORE, EVIDENCE $\& 2212$, at 155 (MCNaughton ed. 1961). In FCC v. Cohn, 154 F. Supp. 899 (S.D.N.Y. 1957), the court responded to an FCC petition for enforcement of an order seeking information on profits, production costs, and sales prices by granting enforcement of the order but imposing restrictions on the agency's voluntary disclosure of the data, noting that it was "in the nature of a trade secret, the disclosure of which might well do great if not irreparable harm to the . . . business." Id. at 912 (footnote omitted).

66. See Doerfer, The Limits on Trade Secret Law Imposed by. Federal Patent and Antitrust Supremacy, 80 HARV. L. ReV. 1432, 1437 (1967).

67. 58 F.T.C. 1184 (1961).

68. Id. at 1189. However, the "irreparable injury" test was found to be too harsh in Graber Mfg. Co. v. Dixon, 223 F. Supp. 1020, 1022 (D.D.C. 1963). 
closure of a traditional trade secret was threatened ${ }^{60}$ While this decision has been incorporated by reference into the Commission's Rules of Practice for the disclosure of confidential information in agency adjudications, ${ }^{70}$ recent FTC decisions have apparently abandoned the dichotomous treatment. In Lehigh Portland Cement, ${ }^{71}$ the Commission adopted the position that trade secrets as well as confidential business information would be protected if disclosure would result in "clearly defined serious injury" to the person or corporation whose records were imvolved. ${ }^{72}$ Furthermore, where the confidential business information involved is current, a presuinption of serious injury is generally established, and disclosure of trade secrets and confidential business information is restrained. ${ }^{73}$

Even if the trade secrets exception to the discretionary publication provision is not broad enough to encompass competitively significant financial information, the FTC may still be restrained from disclosing confidential cost and profit data under general limitations on the disclosure of confidential information. In connection with the protection of busmess secrets in litigation, "courts long have given protection to various types of confidential busmess information on the principle that intentionally inflicted harm is actionable unless privileged."74 Moreover, courts have commonly imposed limitations on the disclosure of confidential business inforination in enforcing administrative orders and subpoenas. ${ }^{75}$ For example, in FTC v. Menzies, $^{76}$ the court enforced an FTC subpoena issued in connection with price discrimination proceedings but imposed restrictions on the

69. 58 F.T.C. at 1189. For a more complete discussion of Hood, see Gellhorn, The Treatment of Confidential Information by the Federal Trade Commission: The Hearing, 116 U. PA. L. REv. 401, 416-19 (1968).

70. See 16 C.F.R. $\$ 3.45(b)$ (1974).

71. 74 F.T.C. 1585 (1968).

72. Id. at 1588 .

73. Gellhorn, supra note 69, at 419. However, the definition of "current" has not been uniform. In Crown Cork \& Seal Co., 71 F.T.C. 1714 (1967), the Commission refused to grant confidential status to a non-party witness' business records which were from two and one-half to six and one-half years old. The Commission stated: "More recent or current records may require different treatment. As to these, although mjury may not be demonstrated, it might be more readily inferred since injury flowing from their disclosure would be more immediate and palpable." Id. at 1715. In National Tea Co., 69 F.T.C. 226 (1966), the FTC let stand a trial examiner's order that sales figures which were seven years old be accorded confidential status. See id. at 272.

74. Gellhorn, supra note 69, at 408 (footnote omitted).

75. Gellhorn, The Treatment of Confidential Information by the Federal Trade Commission: Pretrial Practices, 36 U. ChI. L. REv. 113, 125-26 (1968).

76. 145 F. Supp. 164 (D. Md. 1956), aff'd, 242 F.2d 81 (4th Cir.), cert. denied, 353 U.S. 957 (1957). 
disclosure of the secret business documents involved, stating that "[n]o part of the documentary evidence should be made public and available to the competitors of the several respondent corporations unless it is necessary to do so in the proper enforcement of the law."77 Recently, parties submitting confidential busmess information to the government have been permitted to utilize the exemption in the Freedom of Information Act for confidential commercial information to prevent an agency from voluntarily releasing the confidential information. ${ }^{78}$

Although there are few decisions on the question, the protection accorded confidential business information in judicial proceedings has been extended to restrain the public disclosure of information submitted to agencies in general economic and financial investigations. An important case in this area is $F C C v . C o h n .^{79}$ While in an earlier case the same court had allowed the FTC to compel a company to disclose confidential busmess information to the agency in a general economic investigation without requiring FTC assurances that the information would remain confidential, ${ }^{89}$ the $\operatorname{Coh} n$ decision adopted a different position. Cohn involved an FCC investigation of the structure, operation, and extent of competition in the broadcasting industry. In the course of the investigation, the FCC mailed questionnaires to motion picture and television producers seeking detailed financial information including profits, production costs, and sales prices. When the producers refused to respond to the questionnaires, the FCC brought an action for enforcement. The court enforced the request for information, but enjoined the Commission from publicly disclosing the financial data, noting that disclosure "would not only harm the respondents [producers] but give their competitors unfair advantage." $" 81$

The argument has been made by the opponents of the LB program that the FTC should be prohibited froin publishing the aggregate LB reports because the publication of these reports in the FTC's proposed format will result in the disclosure of imdividual company

77. Id. at 171. See also FTC v. Bowman, 149 F. Supp. 624, 630-31 (N.D. III.), aff'd, 248 F.2d 456 (7th Cir. 1957).

78. 5 U.S.C. $\$ 552(\mathrm{~b})(4)(1970)$; see Note, Developments Under the Freedom of Information Act-1974, 1975 DukE L.J. 416, 427-32; cf. United States Steel Corp. v. Schlesinger, 35 AD. L.2D 790 (E.D. Va., Sept. 20, 1974); Westinghouse Elec. Corp. v. Schlesinger, 34 AD. L.2D 1074 (E.D. Va., Apr. 4, 1974).

79. 154 F. Supp. 899 (S.D.N.Y. 1957).

80. FTC v. National Biscuit Co., 18 F. Supp. 667, 670-71 (S.D.N.Y. 1937).

81. 154 F. Supp. at 913 , 
financial data. ${ }^{82}$ After studying the proposed inethod of publication, a statistical expert has concluded that the aggregate data can be disaggregated to varying degrees by using sophisticated mathematical pattern-recognition techniques, thereby revealing individual company data. ${ }^{83}$ To the extent that the aggregate LB reports can be disaggregated to reveal individual company data, then, measured by the principles elaborated in the foregoing discussion, it would seem that additional measures designed to protect individual company data froin disclosure are mandated before the program can go forward. In the first place, if the trade secrets exception of the publication provision is broad enough to encompass financial data of competitive significance, then the Commission simply lacks the authority to publish the aggregate reports. But even if the trade secrets exception is not

82. See Memorandum of Legal Analysis in Opposition to the Federal Trade Commission's Annual Line-of-Business Program, by Edward T. Tait and Lee A. Rau, Reed, Smith, Shaw \& McClay, July 18, 1974, at 30-31.

83. See generally Memorandum on Disaggregation, supra note 21. In summarizing these conclusions, the statistical expert stated that

it will be possible, using these LOB totals together with other company, market and industry information, to disaggregate the published figures .... [T] publication of $L O B$ data will enable some companies to find out more about their competitors than those competitors will be able to find out about them. Id. at 1 .

He further concluded in a letter accompanying the memorandum:

1. Each company will be able to disaggregate to some extent the data for any series of lines of business it selects, because in many situations it will be able to compute exactly some elements of the [company]-by-[line-of-business] matrix, and in all situations it will be able to bracket the remaining elements within lower and upper limits whose boundaries can be stated with precision. In many of the latter cases, the range between the npper and lower boundaries will be very narrow.

2. Different coinpanies will, in general, be able to disaggregate the line-ofbusiness totals to different extents ....

3. Different coinpanies will, in general, be subject to having their own totals disaggregated by others to different extents . . . .

4. The disaggregation procedure enables each company to determine what additional information would help it to disaggregate even more precisely, and therefore enables it to focus its data search on the most critical items. Letter from Ronald Christensen, Entropy Limited, to Ira M. Millstein, Weil, Gotshal \& Manges, Oct. 26, 1974.

This disaggregation procedure was reviewed by an independent expert who found that Mr. Christensen lias presented very convincing arguments that the publication by [tlie] FTC of certain financial data by line-of-business totals can be used, together with various coinpany, market and industry data, to accurately determine in many situations the breakdown of FTC totals by company or at least to determine exactly certain company contributions to the total and, with the addition of such other ancillary information, it appears possible to estimate the breakdown of many of the remaining company contributions to the line-ofbusiness totals within very narrow linits. Letter from George Dantzig, Professor, Stanford University, to Ira M. Millstein, Weil, Gotshal \& Manges, Oct. 26, 1974.

Disaggregation of figures reported in the QFR report las not been a problen since the average number of firms in each reporting cell is 350 as compared with fifteen for the LB repórt. Bureau Staff Report 25. 
broad enough to include business secrets of this type, it would seein that the general limitations on the disclosure of confidential information should apply in this area.

The Commission itself has implicitly recognized the potential harm involved in the disclosure of this information by its adoption of the LB confidentiality rules, which provide that "no individual company data contained in the Line-of-Business Reports will be revealed in these [aggregate LB] reports ...."84 In addition, the General Counsel of the Commission has explicitly acknowledged that "there could be adverse long range consequences to competition from such disclosure . . . ."85 The thrust of these statements is that individual company statistics slrould be protected from public disclosure; thus, if disaggregation is a possibility, the logical conclusion is that the FTC must redesign the program in order to avoid such public disclosure before any aggregate reports may be published.

\section{CONCLUSION}

As it is currently formulated, the LB program is obviously plagued with many problems. The data that it will generate will contain some inaccuracies, the costs to private industry in providing the FTC with LB information will likely be high, and there is a possibility that some confidential individual company statistics will be disclosed. Yet the program also has the potential to furnish the government and the public with significant product-line information on American industry-information not otherwise currently available. Moreover, even from the point of view of industry, the LB program would seem to have at least one very desirable aspect: it would provide compames with aggregate financial data on their competitors that could be useful in promoting efficient resource allocation and maximum profits in their own operations.

Accordingly, rather than simply abandoning the LB program because of the current difficulties, it would seem that the best solution would be to continue to refine the program through continuing discussion with representatives from the business community in order to eliminate or at least reduce the problems inherent in the program

84. Rules and Procedures for the Use of Confidential Individual Company Data Collected Under the FTC's Line of Business Report Program, 39 Fed. Reg. 30,970 (1974). In other situations, courts have held that agencies must comply with their own rules and regulations. See, e.g., Vitarelli v. Seaton, 359 U.S. 535, 539-40 (1959); United States v. Associated Merchandising Corp., 261 F. Supp. 553, 559 (S.D.N.Y. 1966).

85. Address by Calvin Collier, supra note 25 , at 15 . 
as it is presently designed. Meanwhile, although the FTC seems to have the statutory authority to gather the information notwithstanding the high cost to the companies complying with the LB orders, the FTC should be restrained from publishing even aggregated statistics until it can guarantee that individual company! information will remain confidential. 